\title{
Integration of Islamic banking in the national banking sector: foreign experience
}

\author{
Viktoriia Stoika ${ }^{1, *}$ \\ ${ }^{1}$ University of Science and Technology named after Jan and Jędrzej Śniadecki, Faculty of Management, Bydgoszcz, Poland
}

\begin{abstract}
The rules of banking management in Muslim countries are based on the Sharia Law, that is, a set of rules and laws relating to the management of the economy, social, political and cultural aspects of Islamic society. Sharia Law also prohibits the conclusion of immoral transactions and endorses social justice, which is ensured through the distribution of risks and returns, and the implementation of social investment. In the context of economic globalization, this phenomenon is already quite distinguished and is considered a worthy competitor to the traditional banking system. Features of Islamic banking institutions activities become their advantages in comparison with traditional banking institutions. That is why Islamic banks have become active participants in the global financial market, despite the specific nature of their operations and the difficulties of their adaptation to international practice. Islamic banking has spread not only in the developed countries of Western Europe, but also in Central Asia. The study of the process of Islamic banks activities in the financial markets of such countries as Great Britain, Germany, Kazakhstan and Uzbekistan allows us to identify two forms of their functioning: establishment of Islamic windows by banking institutions of these countries and direct entry of banks that originate from Islamic countries. The experience of the above-mentioned countries regarding the integration of Islamic banking into the national financial sector has shown, first of all, the need to develop an appropriate regulatory framework, to form an appropriate infrastructure, to conduct awareness-raising activities, to strengthen international cooperation with investor countries.
\end{abstract}

\section{Introduction}

The term "Islamic financial system" is relatively new among scientific terms, since it has appeared in the mid1980s. Often, this concept is understood as a financial system in which interest is not provided. However, the principles of Islamic finance are much broader than the rejection of loan interest.

The rules of banking management in Muslim countries are based on the Sharia Law, that is, a set of rules and laws relating to the management of the economy, social, political and cultural aspects of Islamic society. Sharia Law also prohibits the conclusion of immoral transactions and endorses social justice, which is ensured through the distribution of risks and returns, and the implementation of social investment. In the context of economic globalization, this phenomenon is already quite distinguished and is considered a worthy competitor to the traditional banking system.

In today's world, there is an increased interest in Islamic banking and its products. Today, Islamic banks are actively integrating into European countries, as well as other non-Islamic states.

Taking into consideration the rapid development of Muslim banks all over the world, the study of the properties of Islamic banking functioning and the experience of foreign countries concerning adaptation of its instruments to the needs of the national economy is

\footnotetext{
* Corresponding author: viktoriia.stoika@utp.edu.pl
}

relevant and is of important theoretical and practical interest.

Trends and problems in the development of Islamic finance are now relevant topics of scientific researches. The following research and training organizations conduct different academic researches on this issue: Islamic Economic Institute (Jeddah), Institute of Islamic Banking and Insurance (London), Islamic Finance Academy (Dubai), International Centre for Education in Islamic Finance (Kuala Lumpur). Also, the following authoritative international organizations as the Islamic Development Bank, the Accounting and Auditing Organization of Islamic Financial Institutions and the Council of Islamic Financial Services, the World Islamic Economic Forum, etc. study practical issues of the industry development.

The following works of such researchers as O. Abdelsalam [1], M. Abduh, M.A. Omar [2], R.K. Aggarwal, T. Yousef [3], R. Ayachi Ammar, M. Ben Slama, D. Saidane [4], T. Beck, A. DemirgucKunt, O. Merrouche [5], M. Mohieldin [6], S. Ongena, I. Sendeniz-Yuncu [7], M. H. Rashwan [8], M. Djennas [9], J. Boukhatem, Ben Moussa [10] are devoted to the issues of Islamic Finance and Banking.

In recent years, the growing interest in the specifics of Islamic finance and banking is observed among Ukrainian researchers, namely: B. Pshyk [11], N. Pantelejeva [12], O. Mozgovyj, O. Subochev, O. Jurkevych [13], S. Mykhajluta, N. Chuyenko [14], 
O. Chugajev, A. Cherednychenko [15]. Some aspects of the Islamic banking features were also highlighted by the author of the following publication $[16,17]$. However, the attention of the above-mentioned scientists is mainly focused on the features of the formation, development and tools of Islamic banking; while the problem of the Islamic banking model integration in the national banking system is still insufficiently studied.

The research in the field of Islamic banking is conditioned not only by bankers' interest in innovative financial products but also by a variety of interpretations of theoretical foundations of Islamic banking, as well as a discussion on the need to apply the experience of Islamic banks in the traditional financial system.

The aim of the present article is to study the features of the development and integration of Islamic banks at the level of national banking systems.

\section{Methods}

The main methods of scientific knowledge and research of economic phenomena were used to achieve the desired objective, in particular, methods of theoretical generalization and comparison (to determine the specifics of Islamic banking), abstract and logical method (for theoretical generalization and conclusion). The theoretical and methodological basis of this study was the works of foreign and Ukrainian researchers, who study the activities of Islamic banks.

\section{Results}

The term "Islamic banking" means the conduct of banking operations in accordance with the principles of Islam. The main idea of the Islamic bank activity is that, since money is not a commodity, it cannot increase just because it was provided in the form of a loan. In fact, all transactions in financial institutions that operate under the Sharia Law principles are carried out on the basis of responsibility allocation and share participation of both parties - the one that takes the loan and the other that provides the loan. That is, the creditor can expect to receive income only if the money invested in the economy has created real added value. The reward of the bank or a depositor is not guaranteed, but is derived from the profit of the business. Naturally, the bank opens accounts, on which it accumulates funds of depositors and finances entrepreneurs by means of these funds. However, instead of paying the traditional interest, the entrepreneur shares the profit with the bank, which in turn shares with the depositor. It is obvious that under the following circumstances, Islamic banks are absolutely interested in the success of the debtor's business and getting profit, and therefore they choose borrowers with the utmost preciseness. A Muslim banker makes a decision on granting a loan primarily on the basis of studying the prospects of the project, which is proposed for implementation, as well as the business qualities of the borrower. At the same time, Islamic banks do not require the client to provide pledge.

The Islamic economic model is primarily intended to optimize the operation of each party's financial processes. To improve the effectiveness and addressing inequities in economic relations provide the main types of constraints $[17,18]$ :

1. The ban on usury. Rhiba (the surplus) is any unjustified increase of capital in the loan. Any transaction, which depends only on the term and amount of the deposit and not depends on the success of investments is prohibited because of rhiba. Thus, rhiba covers not only usury, but any interest in the usual traditional sense. The prohibition of rhiba is associated with the Islamic view on social justice, equality and property rights [19]. Islam encourages profits only as a result of activities, leading to the formation of any final product, condemning the use of percent in profit.

2. Division of profit, loss or risk. Due to the prohibition of interest, capital owner is not a lender but investor. Thus, there is risk sharing between the owner of capital and the user of capital, as there is no guarantee of regular income. However, in case of success of the project, the investor participates in the direct distribution of profits.

3. Money as "potential" capital. The money will become capital only if it is invested in some business.

4. Prohibition of speculative behaviour. Operations based on the random event or speculation (in Arabic known as "maysir") and not on the action of the parties aimed on generating income are considered to be invalid in Shariah. In this regard, in the Islamic financial system it is extremely complicated to use the derivative financial instruments which have significant risk level. The most of derivatives has no supposed delivery of real base asset, leading to the rapid development of speculation in the financial market. Buying shares with a relatively short holding period (exchange game) can be also attributed to speculation.

5. Sanctity of contract. The indefeasibility condition of the contract is the most important condition of the transaction.

6. Prohibition of uncertainty (gharar). When entering into a contractual relationship, the parties must fully disclose their intentions and information to each other, because the transaction that contains gharar will be prohibited. Any transaction where the subject of the transaction, the price or both are not defined and not fixed in advance will be considered suspicious by the Shariah. Islam condemns obtaining unilateral advantages by more informed party of the contract.

7. The ban on investments violating public interest. Investments inherently must comply with the principles of Shariah. Operations associated with certain types of products are prohibited; such products include pork, alcohol, arms, gambling and traditional fixed-income financial products. Islamic institutions can (depending on the views of the Shariah Council) to face challenges when investing in such activities as hospitality and entertainment industry. Also, the institutes have a black list of prohibited investments composed by the Shariah Council. The mechanism of Islamic capital market is somewhat different from the well-known capital market. Economic agents are guided not only by legal norms laid down in the legislation of the country, but also the rules 
prescribed in the Holy Scripture, the Quran. The transaction under Sharia law must meet six basic principles $[17,18]$ :

1. the interest is prohibited ("rhiba");

2. the risk should be shared;

3. the speculative behaviour is prohibited ("maysir");

4. use of asymmetric information is banned ("gharar");

5. the contracts should be respected;

6. trade transactions allowed by the Islamic norms should be financed only, i.e. financing the Halal industries.

Consider the principle prohibiting the use of asymmetric information in the context of Western economic models and how this principle, which was announced by the Prophet Muhammad 14 centuries ago is applicable today. Gharar (literally, "danger", "error") refers to such a property contract/transaction, which causes deliberate or accidental omissions in the information by one or both of the parties, or party/parties cannot adequately interpret the purpose and expected outcome of the contract.

Islamic view on gharar as information asymmetry is in its ethical interpretation, i.e. Islam condemns obtaining unilateral advantages by more informed party of the contract. Examples of a contract containing gharar are the next: purchase and sale of goods the seller do not possess now; the transaction without specifying the exact price, for example, with the phrase "current market price"; transactions using insider information, etc.

It is important to understand that Islamic economy does not formulate any special laws of economic development, but only alternative methods of doing business, and Islamic financial institutions, as part of the modern world economy, are characterised by the same economic laws as traditional (non-Islamic) financial market participants and partly affected by the same problems that arise in the West [20].

There is a wide variety of Islamic financial products available. Many of them have similarities, however, they are used in different purposes. For a more general presentation the most common of them discussed below.

Musharaka (from Arabic "partnership") is a joint project ofthe Islamic financial institution and the entrepreneur. This product requires the signing of the partnership agreement between an Islamic financial institution and a customer, according to which both parties are funding the project together. Losses are divided in proportion to the participation of parties in the financing. The project may be funded by more than two parties. The project is being managed by all participants or by one of them. Musharaka contracts may be used for providing additional working capital for the company or for joint investments, for example, in real estate or agriculture. This type of contracts is used often to finance long-term investment projects [21].

The following financial instrument that is actively used by Islamic financial institutions is Mudaraba. Mudaraba is typically used to finance short- and medium-term investment projects (e.g. in retail trade). The Mudaraba contracts are analogous to trust-based financing in the traditional financial system. The income generated from the invested money is distributed between the financial institution and the entrepreneur in accordance with the agreement, concluded at the moment of signing the contract. At the conclusion of the contract, the parties determine proportion in which the profits will be divided, and not a specific amount of money (usually Islamic financial institution receives 15 to $30 \%$ of the profits). The financial institution solely bears lossesin case they occur, and the mudarib (the trustee) in that case gets no reward for its efforts. The mudarib (the trustee) has no right to use the funds to finance other projects not covered by the contract without the permission of the client, and cannot attract other sources of funding or to use its own money.

Ijara is a copy of a leasy transaction in the traditional financial system. It involves an agreement by which Islamic financial institution buys equipment, real estate, etc. at the customer's request, and then renting it to the customer. The duration of the lease and rent fee (fixed or time-varying) agreed by the parties.

Under Murabaha contract Islamic financial institution provides trade financing. Murabahais accompanied by a contract of sale of goods between the bank and its client at an agreed price. The bank buys the goods (raw materials, component parts, etc.) on behalf of the client, and then resells the goods to him, profiting from the sale of the goods, and also extra charge for services rendered. After signing the contract, the bank agrees to provide to the customer the goods, and the date and place of receipt of goods specified in advance. Before the goods are received by customer, the Islamic financial institution bears all risks of spoilage or damage.

The price of the goods should be determined in advance, and should specify the amount of markup, which is the reward. The client should pay the requested amount (usually gradually - in the form of an annuity payment) within a specified and fixed by the contract time period or as a lump sum. The margin for the bank's services can be specified in monetary terms or as a fraction of the cost of the goods, but must in no way be associated with time expressions ("weekly", "monthly", etc. are not allowed). The client in this type of transaction usually provides collateral to secure Islamic financial institution [18].

Thus, the Islamic banking system, like any other, is aimed at making a profit, but its main difference is the methodology and compliance with Sharia Law. There is a certain set of rules how to make a profit. The fundamental difference and the basic principle of the Islamic bank is the mutual distribution of both costs and risks, and income. While the basic principle in the traditional system is "money makes money". There is no speculation, and the profit depends on which sector the money is invested in and what share of the assets the depositor is entitled to claim.

Therefore, there are three main values in the Islamic bank system: the development of entrepreneurship and entrepreneurial skills; the development of trade and commerce; the ability to benefit the whole society.

In addition, there are some prohibitions in Islamic banking related to Sharia Law: usury or loans at interest; 
gambling earnings; speculation in the market; money of Islamic banks cannot be used for immoral purposes (drug trafficking, alcohol trade, etc.).

Over the past twenty years, the Islamic finance sector has experienced significant growth and today the volume of assets is about $\$ 1.814$ trillion (a six-fold increase over the past decade). Most transnational financial institutions participate in some form in Islamic finance as global banking, investment, consulting, accounting or information companies. Nowadays, Islamic financial institutions operate in at least 105 countries and more of them have already implemented (or are considering implementation of legislation to provide a regulatory framework for the development of this type of financial industry.

In the Islamic world, Islamic financial institutions are major economic players. Five countries dominate in Islamic banking, namely Iran with $\$ 345$ billion of Islamic assets; followed by Saudi Arabia ( $\$ 258$ billion), Malaysia ( $\$ 142$ billion), Kuwait ( $\$ 128$ billion) and the United Arab Emirates (\$112 billion). Except for Islamic countries, the industry is actively developing in many non-Muslim countries - mainly in Western Europe, the USA, Canada and Australia as a consumer segment (focused on local communities of Muslim immigrants) and corporate segment (focused primarily on attracting investment from oil-producing countries of the Persian Gulf). The greatest success in this direction was achieved by Great Britain: 22 Islamic banks with the assets value of $\$ 19$ billion (according to only six banks) and 34 Islamic investment funds with the assets value of $\$ 300$ million are operating on its territory; and 43 sukuk for a total amount of $\$ 24$ billion were allocated on the London Stock Exchange. The experience of Great Britain shows that Islamic finance can be an attractive market segment for the existing banking sector, where from 22 Islamic banks 17 of them are Islamic windows of local traditional banks and only 5 of them are fullfledged Islamic banks founded by the investors from the Persian Gulf countries [13].

Today, London is the world's largest market for Islamic bonds. This is due to the global expansion of Islamic finance; global leadership positions of Great Britain in financial innovations, which has a strong potential of legal, accounting and financial engineering; excess liquidity in the Middle East; creation of regional offices in the Middle East and Asia, market research, improvement of the product line (Islamic windows); creation of a single financial regulator - Financial Services Authority, which replaced 11 regulatory bodies; elimination of double taxation on Islamic mortgages and expansion of tax benefits for Islamic mortgages to companies as well as individuals; reform of bond arrangements.

Federal Financial Supervisory Authority, the main Agency that regulates the banking sector, has issued a limited license to conduct banking activities of the Kuveyt Turk Participation Bank. The controlling stake in this bank belongs to Kuwait Finance House, one of the largest Islamic banks in terms of assets value. Among other shareholders - the Islamic Development Bank, which has a 9\% stake in the Kuveyt Turk Participation Bank.

Kuveyt Turk has a branch in the city of the same name, and the current issuance of the license, even if limited, actually means an increase in the status and powers of its German representative office.

It should be noted the so-called Islamic windows are also common in Germany, a number of financial institutions have them; in particular, Deutsche Bank, Hypo Real Estate Bank, Commerzbank and insurance companies such as Allianz and FWU AG, which distribute such Islamic financial products as real estate transactions, direct private investment, as well as transactions with Islamic securities [14].

The first Islamic bank in the territory of CIS countries was Islamic Bank Al Hilal, established in 2010 in Kazakhstan. This financial institution is a subsidiary bank of Al Hilal Bank PJSC, which is one of the most progressive and developed Islamic state-owned banks in the United Arab Emirates.

Al Hilal Bank PJSC has a high credit rating from Fitch Ratings and A2 from Moody's, which is an indicator of financial stability and reliability of the bank. In 2017, after seven years of successful work in the corporate sector, the bank began to provide Islamic banking products to individuals. Al Hilal Bank designed to actively contribute to the development and prosperity of the national economy by providing Islamic financial services to corporate clients and population.

It should be noted that in March 2012, the government of the Republic of Kazakhstan approved the Roadmap for the development of Islamic finance until 2020 in order to further implementation of financial and banking services on the principles of Islam [22]. According to this document, the work on the integration of Islamic banking in the country should be carried out in the following areas:

1) improvement of legislation, in particular, development of additional recommendations for improvement of legislation on Islamic finance with the assistance of domestic and international consultants, consideration of the feasibility and necessity of establishing a separate legal framework for the functioning of Islamic non-banking and microfinance institutions (investment funds, leasing and mortgage companies), as well as companies with the status of Islamic professional participants in the securities market;

2) awareness-raising activities, in particular, the preparation and implementation of the media plan, consideration of the possibility of creating a special Internet portal dedicated to Islamic finance;

3) development of Islamic financial infrastructure, in particular, consideration of the possibility of establishing a Central Council for Islamic finance and establishing a regional Islamic financial center in Almaty city;

4) development of international cooperation, in particular, establishment of cooperation with international organizations including General Council of Islamic Banks and Financial Institutions, Accounting and Auditing Organization for Islamic Financial Institutions, International Islamic Financial Market, 
International Islamic Rating Agency, Islamic Financial Services Board, Islamic Solidarity Fund for Development, Islamic Liquidity Management Centre;

5) development of the public sector, in particular, consideration of the establishment of the Committee for Development of Islamic Finance under the National Bank of the Republic of Kazakhstan, implementation of the special intergovernmental program (twinning) for the study and experience exchange with the countries that have successfully implemented and develop the system of Islamic finance (Malaysia, Bahrain, UAE, Great Britain, USA, Luxembourg);

6) development of the Islamic financial services market, in particular, facilitating establishment of several Islamic banks and introduction of Islamic insurance;

7) scientific and educational work, in particular, the study of the methodology and experience of the Islamic financial industry and establishment of an educational and analytical center for the study of Islamic finance on the basis of Kazakh higher educational establishments, holding round tables with the involvement of scientists and practitioners;

8) cooperation with investors, in particular, conducting targeted negotiations and meetings with banks, funds, companies of the countries of South-East Asia and the Middle East in order to attract investments to Kazakhstan (financing of the investment project, conclusion of agreements), considering the possibility of carrying out organizational measures on the territory of the Republic of Kazakhstan (including Kazakhstan Islamic Financial Conference).

Almost all relevant ministries (Ministry of Foreign Affairs, Ministry of Industry and New Technologies, Ministry of Finance, Ministry of Economic Development and Trade, Ministry of Justice, Ministry of Education and Science, etc.), National Bank, National Economic Chamber, Association of Financiers of the Republic of Kazakhstan and a number of other institutions are involved in the implementation of the Roadmap for the development of Islamic finance until 2020.

Islamic banking is also being actively developed in the territory of Uzbekistan. In particular, in May 2018, the draft resolution of the President of Uzbekistan "On measures to establish the infrastructure of Islamic banking and finance in the Republic of Uzbekistan" [23] was published on the portal for the discussion of draft regulatory legal acts. In order to create alternative financing opportunities and meet the growing needs of the population and entrepreneurs, to expand the range of banking and financial services offered, to mobilize financial resources from the domestic and foreign markets on the basis of Islamic banking and finance principles, it was proposed, in particular, to form a Commission on the development and implementation of Islamic banking and finance principles. The working body of this Commission is the initiative group, which was established by the Ministry of Finance from among experts and specialists in the field of Islamic finance. The Commission will carry out activities to establish the necessary financial infrastructure in Uzbekistan, develop and submit regulatory legal acts on the implementation of Islamic banking and finance principles for approval by the law. The Commission is also responsible for coordinating the activities of ministries, agencies and other interested organizations in order to facilitate the prompt consideration, agreement and approval of draft relevant regulatory legal acts. In addition, the Commission will take measures to widely publicize the advantages and opportunities of using banking and financial services based on the principles of Islamic banking and finance among the population and business entities, as well as to explain their main differences from traditional banking services. On the completion of the working draft, the Commission is entitled to submit a draft decision of the President of the Republic of Uzbekistan on the establishment of the Islamic Development Bank of Uzbekistan in accordance with the established legislation.

It should be noted that in September 2018, the Islamic Development Bank (IDB) and Uzbekistan signed a partnership strategy for 2018 - 2021, which provides allocation of $\$ 1.3$ billion to the Central Asian country. In general, since 2003, in which Uzbekistan became a member of the IDB, the Bank has allocated \$1.9 billion for the implementation of various projects in the country [24].

\section{Conclusion}

Consequently, Islamic banks entered the financial markets and managed to occupy a niche in the global investment process. Islamic finance is based on the principles of trust, respect, risk sharing, compliance with the commitments and fair distribution of profit. This ensures the interest of Islamic banks in the final result of their activities, unlike conventional banks, which focus only on obtaining their own profit. An Islamic banking model has a specific set of properties contributing to formation of sustainable development of not only the banking market but also the financial market as a whole. Features of Islamic banking institutions activities become their advantages in comparison with traditional banking institutions. That is why Islamic banks have become active participants in the global financial market, despite the specific nature of their operations and difficulties of their adaptation to international practice. Islamic banking has spread not only in the developed countries of Western Europe, but also in Central Asia. The study of the process of Islamic banks activities in the financial markets of such countries as Great Britain, Germany, Kazakhstan and Uzbekistan allows us to identify two forms of their functioning: establishment of Islamic windows by banking institutions of these countries and direct entry of banks that originate from Islamic countries. The experience of the abovementioned countries regarding the integration of Islamic banking into the national financial sector has shown, first of all, the need to develop an appropriate regulatory framework, to form an appropriate infrastructure, to conduct awareness-raising activities, to strengthen international cooperation with investor countries. The practical use of characteristics of the Islamic banking 
model is a promising direction in addressing the challenges of innovative banking products and services generation and modern banking modernization.

\section{References}

1. Abdelsalam, O., Fethi, M.D., Matallín, J.C., Tortosa-Ausina, E.: On the comparative performance of socially responsible and Islamic mutual funds. Journal of Economic Behavior and Organization. 103, 108-128 (2014)

2. Abduh, M., Omar, M.A.: Islamic banking and economic growth: The Indonesian experience. International Journal of Islamic and Middle Eastern Finance and Management. 5(1), 35-47 (2012)

3. Aggarwal, R.K., Yousef, T.: Islamic banks and investment financing. Journal of Money, Credit and Banking. 32(1), 93-120 (2000)

4. Ayachi Ammar, R., Ben Slama, M., Saidane, D.: Does the current practice of Islamic banks encourages growth? Studies in Islamic Economics. 6(1-2), 57-82 (2013)

5. Beck, T., Demirguc-Kunt, A., Merrouche, O.: Islamic vs. conventional banking: Business model, efficiency, and stability. Journal of Banking and Finance. 37, 433-447 (2013)

6. Mohieldin, M., Zamir, I., Ahmed, R., Xiaochen, Fu: The role of Islamic finance in enhancing financial inclusion in Organization of Islamic Cooperation (OIC) countries. Islamic Economic Studies. 20(2), 55-120 (2012)

7. Ongena, S., Sendeniz-Yuncu, I.: Which firms engage small, foreign, or state banks? And who goes Islamic? Evidence from Turkey. Journal of Banking and Finance. 35(12), 3213-3224 (2011)

8. Rashwan, M.H.: How did listed Islamic and traditional banks perform: Pre and post 2008 financial crisis? Journal of Applied Finance and Banking. 2(2), 149-175 (2012)

9. Djennas, M.: Business cycle volatility, growth and financial openness: Does Islamic finance make any difference? Borsa Istanbul Review. 16(3), 121-145 (2016)

10. Boukhatem, J., Ben Moussa, F.: The effect of Islamic banks on GDP growth: Some evidence from selected MENA countries. Borsa Istanbul Review, 18(3), 231-247 (2019)

11. Pshyk, B.I.: Islamska finansova model: osoblyvosti, finansovi instrument, svitovi tendenciji (The Islamic financial model: features, financial instruments, global trends). Visnyk Univ. bankivskoji spravy Natsionalnogo banku Ukrajiny. 2(17), 20-24 (2013)

12. Pantelejeva, N.M.: Islamska bankivska sprava: sutnist, innovatsiji ta reguluvannia (Islamic banking: essence, innovation and regulation). Naukovyj visnyk: Finansy, banky, investyciji. 3, 58-63 (2012)
13. Mozgovyj, O.M., Subochev, O.V., Jurkevych, O.M.: Suchasnyj stan industriji islamskykh finansiv: statystyka jakisnogo rozvytku (Current state of islamic finance industry: development data). Investyciji: praktyka ta dosvid. 7, 8-14 (2017)

14. Mykhajluta, S.L., Chuyenko, N.A.: Vyjavlennia faktoriv zabezpechennia stijkosti bankivskoji systemy na osnovi doslidjennia osoblyvostej islamskykh i jevropejskykh bankiv (An exposure of factors of providing of firmness of banking system is on basis of research of features of Islam and European banks). Visnyk Univ. bankivskoji spravy Natsionalnogo banku Ukrajiny. 3, 12-17 (2015)

15. Chugajev, O.A., Cherednychenko, A.V.: Islamskyj banking ta jogo finansovi instrumenty $\mathrm{v}$ koncepciji potencijnoji modeli finansovoji systemy (Islamic banking and its financial instruments in the concept of potential financial system model). Ekonomichnyj chasopys-XXI. 3-4, 13-16 (2011)

16. Stoika, V.S.: Osoblyvosti funkcionuvannia islamskykh bankiv (The features of the functioning of Islamic banks). In: Proc. of $9^{\text {th }}$ economic discussion, Lviv, Dec. 2015, pp. 64-67 (2015)

17. Stoika, V.S., Sember, S.V., Legeza, N.E.: Islamski banky: osoblyvosti funkcionuvannia i rozvytku (Islamic banks: the specifics of their functioning and development). Ekonomika promyslovosti. 1(73), 516 (2016)

18. Nikonova, T., Kokh, I., Safina, L.: Principles and instruments of Islamic financial institutions. Procedia Economics and Finance. 24, 479-484 (2015)

19. Paldi, C.: Understanding riba and gharar in Islamic finance. Journal of Islamic Banking and Finance. 2(1), 249-259 (2014)

20. Bekkin, R.I.: Islamic economic model and modernity. Marjani Publishers, Moscow (2009)

21. Asmadi, M.N.: Purchase Undertaking Issues in Musharakah Mutanaqisah Home Financing. In: Foundations of Islamic Financial Series Second Conference: Islamic Banking Products, Theory, Practice \& Issues, 8-10 March 2011, vol. 3, pp. 147$162(2011)$

22. On the approval of the Roadmap for the development of Islamic finance until 2020. http://www.istisna.kz/eng/img/Road-Map-IF-Deve lopment-20202.pdf (2012). Accessed 10 Mar 2019

23. On measures to establish the infrastructure of Islamic banking and finance in the Republic of Uzbekistan.

https://www.mf.uz/media/file/insurance/postanovlen iya/proekt.pdf. (2018). Accessed 10 Mar 2019

24. The Islamic Development Bank and Uzbekistan signed an agreement for $\$ 1.3$ billion. https://www.fergananews.com/news/32782 (2018). Accessed 10 Mar 2019 